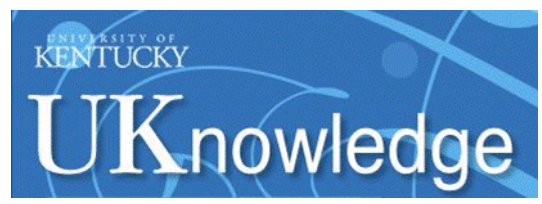

University of Kentucky

UKnowledge

$11-25-2014$

\title{
Catechol Oxidation by Ozone and Hydroxyl Radicals at the Air- Water Interface
}

\author{
Elizabeth A. Pillar \\ University of Kentucky, epillar86@gmail.com \\ Robert C. Camm \\ University of Kentucky, robert.camm@uky.edu \\ Marcelo I. Guzman \\ University of Kentucky, marcelo.guzman@uky.edu
}

Follow this and additional works at: https://uknowledge.uky.edu/chemistry_facpub

Part of the Analytical Chemistry Commons, Environmental Chemistry Commons, Environmental

Engineering Commons, Organic Chemistry Commons, Other Environmental Sciences Commons, and the Physical Chemistry Commons

Right click to open a feedback form in a new tab to let us know how this document benefits you.

\section{Repository Citation}

Pillar, Elizabeth A.; Camm, Robert C.; and Guzman, Marcelo I., "Catechol Oxidation by Ozone and Hydroxyl Radicals at the Air-Water Interface" (2014). Chemistry Faculty Publications. 38.

https://uknowledge.uky.edu/chemistry_facpub/38

This Article is brought to you for free and open access by the Chemistry at UKnowledge. It has been accepted for inclusion in Chemistry Faculty Publications by an authorized administrator of UKnowledge. For more information, please contact UKnowledge@lsv.uky.edu. 


\section{Catechol Oxidation by Ozone and Hydroxyl Radicals at the Air-Water Interface}

\section{Digital Object Identifier (DOI)}

http://dx.doi.org/10.1021/es504094x

\section{Notes/Citation Information}

Published in Environmental Science \& Technology, v. 48, no. 24, p. 14352-14360.

Copyright @ 2014 American Chemical Society

ACS AuthorChoice - This is an open access article published under an ACS AuthorChoice License, which permits copying and redistribution of the article or any adaptations for non-commercial purposes. 


\title{
Catechol Oxidation by Ozone and Hydroxyl Radicals at the Air- Water Interface
}

\author{
Elizabeth A. Pillar, Robert C. Camm, and Marcelo I. Guzman* \\ Department of Chemistry, University of Kentucky, Lexington, Kentucky 40506, United States \\ Supporting Information
}

ABSTRACT: Anthropogenic emissions of aromatic hydrocarbons promptly react with hydroxyl radicals undergoing oxidation to form phenols and polyphenols (e.g., catechol) typically identified in the complex mixture of humic-like substances (HULIS). Because further processing of polyphenols in secondary organic aerosols (SOA) can continue mediated by a mechanism of ozonolysis at interfaces, a better understanding about how these reactions proceed at the airwater interface is needed. This work shows how catechol, a molecular probe of the oxygenated aromatic hydrocarbons present in SOA, can contribute interfacial reactive species that enhance the production of HULIS under atmospheric conditions. Reactive semiquinone radicals are quickly

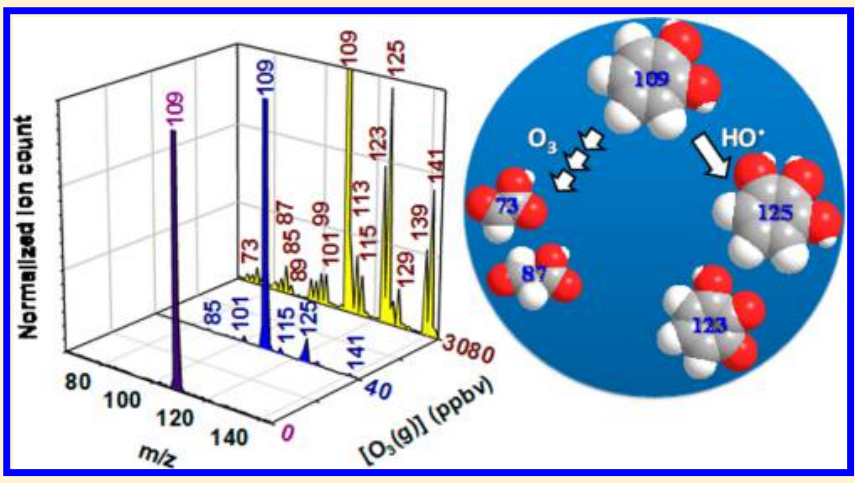
produced upon the encounter of $40 \mathrm{ppbv}-6.0 \mathrm{ppmv} \mathrm{O}_{3}(\mathrm{~g})$ with microdroplets containing [catechol] $=1-150 \mu \mathrm{M}$. While the previous pathway results in the instantaneous formation of mono- and polyhydroxylated aromatic rings (PHA) and chromophoric mono- and polyhydroxylated quinones (PHQ), a different channel produces oxo- and dicarboxylic acids of low molecular weight (LMW). The cleavage of catechol occurs at the 1,2 carbon-carbon bond at the air-water interface through the formation of (1) an ozonide intermediate, (2) a hydroperoxide, and (3) cis,cis-muconic acid. However, variable [catechol] and $\left[\mathrm{O}_{3}(\mathrm{~g})\right]$ can affect the ratio of the primary products (cis,cis-muconic acid and trihydroxybenzenes) and higher order products observed (PHA, PHQ and LMW oxo- and dicarboxylic acids). Secondary processing is confirmed by mass spectrometry, showing the production of crotonic, maleinaldehydic, maleic, glyoxylic, and oxalic acids. The proposed pathway can contribute precursors to aqueous SOA (AqSOA) formation, converting aromatic hydrocarbons into polyfunctional species widely found in tropospheric aerosols with light-absorbing brown carbon.

\section{INTRODUCTION}

Aerosol particles play a key role in climate by scattering and absorbing sunlight and to a lesser extent by absorbing, scattering, and re-emitting terrestrial radiation. ${ }^{1}$ In addition, aerosols can serve as cloud condensation nuclei and ice nuclei upon which cloud droplets and ice crystals form. ${ }^{1}$ The mechanisms of production and the properties of secondary organic aerosols (SOA) from laboratory and field studies have been reviewed. ${ }^{2,3}$ Atmospheric transport and in situ photooxidative surface processing of the species found in aerosols contribute to the large complexity of these systems, making the quantification of photo-oxidative aging complicated. ${ }^{4}$ In this context, recent field measurements of the concentration of water-soluble organic compounds (WSOC), including dicarbonyls (e.g., glyoxal), oxocarboxylic acids (e.g., glyoxylic and 3oxopropoanoic acids), dicarboxylic acids (e.g., oxalic acid), and unsaturated carboxylic acids (e.g., fumaric and maleic acids), suggested common natural sources and/or similar formation pathways. ${ }^{5}$ Similarly, measurements of the distribution ratio of oxalic acid to levoglucosan over the open ocean suggested that photo-oxidative mechanisms control the chemical composition of marine SOA. ${ }^{6,7}$ The high levels of dicarbonyls and oxo- and dicarboxylic acids quantified in aerosols at dissimilar locations, such as the Brazilian Amazon, Singapore, and the summit (1534 $\mathrm{m}$ above sea level) of Mount Tai in central east China, far exceeded those reported in Chinese megacities at ground levels, ${ }^{8-10}$ demanding an explanation to the origin of these important SOA species.

Correlations between the content of WSOC and the transport of biomass-burning products as well as with photooxidative processing during atmospheric transport were established at different sites. ${ }^{8-10}$ The photooxidation of species, such as glyoxylic acid, results in the final production of oxalic acid in the aerosol aqueous phase. ${ }^{8}$ Catechol, hydroquinone, and resorcinol are typically the major gas-phase organic constituents $(\sim 50 \mathrm{ppbv})$ resulting from biomass burning. ${ }^{11}$ Interestingly, cloudwater rich in light-absorbing compounds was also collected at Mount Tai and characterized to contain aromatic species, such as phenol and catechol, with $-\mathrm{CH}_{3}$,

Received: August 20, 2014

Revised: November 25, 2014

Accepted: November 25, 2014

Published: November 25, 2014 
$-\mathrm{NO}_{2}$, and $-\mathrm{C}=\mathrm{O}$ substituents. ${ }^{12}$ These ubiquitous surfaceactive species are enriched in interfacial regions ${ }^{13}$ of atmospheric aerosols and susceptible to photooxidation, ${ }^{14}$ because they reside at the air-water interface.

The heterogeneous ozonolysis of catechol has been the subject of recent studies focused on monitoring the reaction products by Fourier transform infrared spectroscopy (FTIR) on the surface of (1) thin solid films under high relative humidity $(\mathrm{RH})^{15}$ and (2) reactant adsorbed over $\mathrm{NaCl}$ and $\mathrm{Al}_{2} \mathrm{O}_{3}$ particles that produce cis,cis-muconic acid and traces of oxalic acid. ${ }^{16}$ The ring opening of catechol and the formation of unsaturated carboxylic acid was observed in an aerosol flow reactor. ${ }^{17} \mathrm{~A}$ maximum uptake coefficient of $5.6 \times 10^{-5}$ was measured at $\mathrm{RH}=81 \%$ for $\left[\mathrm{O}_{3}(\mathrm{~g})\right]=4 \mathrm{ppmv}$ at $298 \mathrm{~K}^{15}$ The theoretical rate constant for the ozonolysis of catechol, $k_{\mathrm{O}_{3}}+$ cat $=3.4 \times 10^{-25} \mathrm{~cm}^{3}$ molecules ${ }^{-1} \mathrm{~s}^{-1}$, and associated lifetimes of $4.3 \mathrm{~h}$ on $\mathrm{NaCl}$ and $18 \mathrm{~h}$ in $\mathrm{Al}_{2} \mathrm{O}_{3}$ were estimated for typical unpolluted tropospheric conditions $\left(\left[\mathrm{O}_{3}(\mathrm{~g})\right]=40 \mathrm{ppbv}\right){ }^{16}$ However, the typical methods employed for studying heterogeneous reactions [diffuse reflectance infrared Fourier transform spectroscopy (DRIFTS) - and attenuated total reflectance (ATR)-FTIR] require several minutes, resulting in the oversight of structural information at the early stages of ozonolysis. ${ }^{17}$ The ozonolysis of thin films of catechol at high $\mathrm{RH}$ monitored by FTIR is discussed further in the Supporting Information. However, the importance of ozonolysis remains uncertain, and no mechanistic comparison to $\mathrm{OH}$-initiated chemistry was considered. Therefore, further in situ studies providing fast mechanistic information $\left(\sim 10^{-6}<\right.$ time scale $<$ $10^{-3} \mathrm{~s}$ ) of the interfacial oxidation of catechol are needed to comprehend better the fate of biomass-burning emissions.

In this paper, catechol is used as a molecular probe to study the ozonolysis of surface-active organic matter present in atmospheric aerosols. A customized electrospray ionization (ESI) mass spectrometry (MS) system is used to study reactions at the air-water interface with ultrafast contact $\left(\tau_{\mathrm{c}} \sim\right.$ $1 \mu \mathrm{s})$ and detection $\left(\tau_{\mathrm{d}} \sim 1 \mathrm{~ms}\right)$ times. $^{18,19}$ Spectroscopic features reveal the interfacial production of short-lived species that agree with observations in bulk water ${ }^{20}$ but escaped detection in experiments at the air-water interface. ${ }^{15}$ Experiments reveal two reactive channels are operative at the airwater interface: (1) hydroxylation and (2) oxidative cleavage of the aromatic ring. ${ }^{21}$ The first channel operates through semiquinone radicals that are instantaneously converted to mono- and polyhydroxylated aromatic rings (PHA) and monoand polyhydroxylated quinones (PHQ). The second channel is the ultrafast cleavage of the 1,2 carbon-carbon bond of catechol, which proceeds through the consecutive formation of (1) moloozonide, (2) hydroperoxide, and (3) cis,cis-muconic acid (MA). Furthermore, experiments with variable [catechol] and $\left[\mathrm{O}_{3}(\mathrm{~g})\right]$ modify the ratio of primary products (MA and monohydroxylated catechol). Additional evidence of secondary processing is registered by MS measurements that confirm the production of methacrylic acid, maleinaldehydic acid, maleic acid, glyoxylic acid, oxalic acid, PHA, and PHQ. This work shows that tropospheric humic-like substances (HULIS) ${ }^{22}$ precursors can be produced by interfacial reactions of hydroxylated aromatics that contribute reactive chemical species in situ produced in atmospheric particles. ${ }^{21}$

\section{EXPERIMENTAL SECTION}

Solutions of catechol (Sigma-Aldrich, 99.9\%) were prepared daily in ultrapure water $(18.2 \mathrm{M} \Omega \mathrm{cm}$, ELGA PURELAB flex, Veolia) and infused into a calibrated ESI-MS (Thermo Scientific, MSQ Plus). Experiments were performed between $\mathrm{pH} 5$ and 10. Figures report the ion count $\left(I_{m / z}\right)$ at specific mass-to-charge $(\mathrm{m} / \mathrm{z})$ ratios for experiments at $\mathrm{pH} 8.0$, unless otherwise indicated. The $\mathrm{pH}$ of solutions was adjusted with $0.01 \mathrm{M} \mathrm{NaOH}$ (Fisher, 99.3\%) and measured with a calibrated $\mathrm{pH}$-meter (Mettler Toledo). In selected experiments, $\mathrm{KOH}$ (Acros, ACS grade) or $\mathrm{LiOH}\left(\mathrm{LiOH} \cdot \mathrm{H}_{2} \mathrm{O}\right.$, Fisher, laboratory grade) were used to adjust the $\mathrm{pH}$ and verify that the species reported are not clusters that could include alkali metals. All species are in the aqueous state, unless indicated otherwise.

The ESI-MS experimental setup to study the instantaneous formation of short-lived intermediates at the liquid-gas interface was previously described in detail. ${ }^{18,19}$ In order to prepare solutions of catechol to be tested, a typical mixing ratio range of $P_{\text {catechol }}=5-50 \mathrm{ppbv}$ from biomass-burning emissions is considered, ${ }^{11}$ together with the vapor pressure of water $P_{\mathrm{H}_{2} \mathrm{O}}$ $=0.0312 \mathrm{~atm}$ (at $298 \mathrm{~K})^{23}$ and Henry's law constant $H_{\mathrm{o}}^{\text {catechol }}=$ $4600 \mathrm{M} \mathrm{atm}^{-1}$ (at $298 \mathrm{~K}$ ). Therefore, a broad range of $22 \leq$ [catechol] $\leq 223 \mu \mathrm{M}$ is obtained as an estimate for atmospheric waters in contact with pollution from biomass burning. In present experiments, a solution of $1-150 \mu \mathrm{M}$ catechol is pneumatically aerosolized into fine micrometer size droplets at atmospheric pressure and encounters a $0.2 \mathrm{~L} \mathrm{~min}^{-1}$ flow of 40 $\mathrm{ppbv} \leq\left[\mathrm{O}_{3}(\mathrm{~g})\right] \leq 6.0 \mathrm{ppmv}$, both interacting during a contact time of a few microseconds. ${ }^{18,19}$ A spark discharge ozone generator (Ozone Solutions) fed with $\mathrm{O}_{2}(\mathrm{~g})$ (Scott-Gross, $\mathrm{UHP})$ is used for $\mathrm{O}_{3}(\mathrm{~g})$ production. $\mathrm{O}_{3}(\mathrm{~g})$ is diluted with $\mathrm{N}_{2}$ (g) (Scott Gross, UHP) and monitored in a $10 \mathrm{~cm}$ path length cuvette (Starna cell) by ultraviolet (UV) absorption spectrophotometry. ${ }^{24}$ Gaseous ozone is transported to a stainless-steel tube, where a final 61 times dilution with the $\mathrm{N}_{2}(\mathrm{~g})$ nebulizing gas $\left(12.0 \mathrm{~L} \mathrm{~min}^{-1}\right)$ occurs to yield information that covers the low $\left[\mathrm{O}_{3}(\mathrm{~g})\right]$ found in the troposphere.

The encounter of $\mathrm{O}_{3}(\mathrm{~g})$ with the microdroplets containing catechol produces oxidized species reported as anions for specific $\mathrm{m} / z$ values. The overall time from the formation of droplets, transport through the $\mathrm{O}_{3}(\mathrm{~g})$ plume, and ion detection is $\tau_{\mathrm{d}}<1 \mathrm{~ms}$. However, the contact time $\left(\tau_{\mathrm{c}}\right)$ between $\mathrm{O}_{3}(\mathrm{~g})$ and the plume of microdroplets was previously described to be in the order of a few microseconds. ${ }^{19}$ In summary, the experimental conditions were as follows: drying gas temperature, $250{ }^{\circ} \mathrm{C}$; nebulizer voltage, $-1.9 \mathrm{kV}$; cone voltage, $-50 \mathrm{~V}$; and nebulizer pressure, 70 psi. Ion counts reported correspond to processed data after solvent background subtraction from the raw sample mass spectral data acquired at fixed time intervals (e.g., time $\geq 30 \mathrm{~s}$ ). All identified species are indicated by their $\mathrm{m} / \mathrm{z}$ values in the text and schemes. Reported data are the average of duplicate experiments with error bars corresponding to 1 standard deviation.

\section{RESULTS AND DISCUSSION}

Reactions of Catechol at the Air-Water Interface. The ozonolysis of micromolar concentrations of catechol at the airwater interface was monitored under variable $\left[\mathrm{O}_{3}(\mathrm{~g})\right]$. Figure 1 shows ESI mass spectra of aerosolized solutions of catechol in water at $\mathrm{pH} 8.0$ exposed to a flow of $0.2 \mathrm{~L} \mathrm{~min}^{-1}$ (A) 1 atm $\mathrm{N}_{2}(\mathrm{~g})$ (bottom purple trace), (B) $40 \mathrm{ppbv} \mathrm{O}_{3}(\mathrm{~g})$ (center blue 


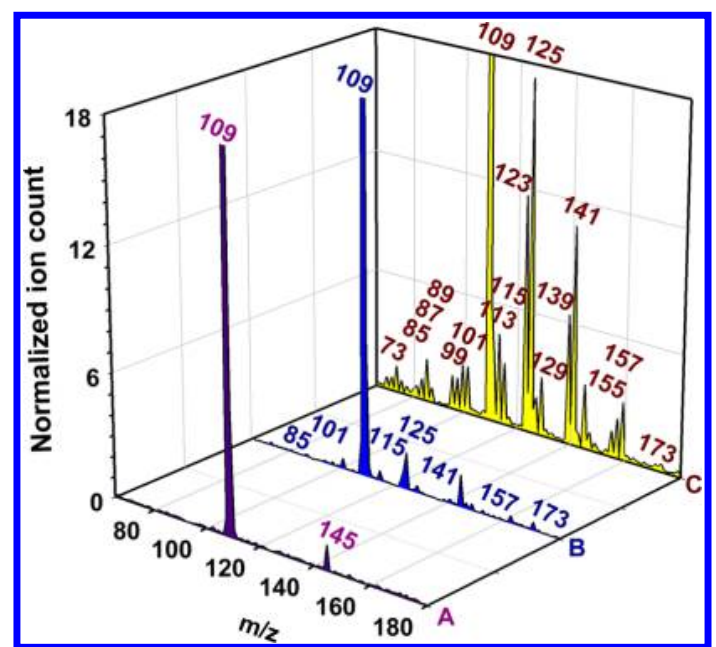

Figure 1. Spectra of ESI-MS of $100 \mu \mathrm{M}$ solution of catechol in $\mathrm{H}_{2} \mathrm{O}$ at $\mathrm{pH} 8.0$ exposed to a $0.200 \mathrm{~L} \mathrm{~min}^{-1}$ flow of (A) 1 atm $\mathrm{N}_{2}(\mathrm{~g})$ (bottom purple trace), (B) $40 \mathrm{ppbv} \mathrm{O}_{3}$ (g) (center blue trace), and (C) 3.08 ppmv $\mathrm{O}_{3}(\mathrm{~g})$ in $\mathrm{H}_{2} \mathrm{O}$ (top yellow trace). Ion count values are normalized percentages relative to $I_{109}$, the most intense peak in the mass spectrum, and the scale only shows signals up to $18 \%$.

trace), and (C) 3.08 ppmv $\mathrm{O}_{3}(\mathrm{~g})$ (top yellow trace). The control measurement in the absence of ozone (bottom trace in Figure 1) only displays the detectable monoanion of catechol $\mathrm{C}_{6} \mathrm{H}_{4}(\mathrm{OH}) \mathrm{O}^{-}(\mathrm{m} / z$ 109) and a minor accompanying peak corresponding to the cluster of catechol anion with two water molecules $(\mathrm{m} / z$ 145). Major changes are observed upon addition of $40 \mathrm{ppbv} \mathrm{O}_{3}(\mathrm{~g})$ (central trace) that results in the appearance of several small peaks because of the immediate oxidation of catechol that does not require an induction period longer than the contact time. The ion count of these new peaks generally increases as the ozone level rises to $3.08 \mathrm{ppmv}_{3}(\mathrm{~g})$ (top trace), and a few additional peaks appear.

Previous studies of the ozonolysis of catechol in bulk water did not address all of the uncertainties existing in the mechanism ${ }^{20,25}$ but are helpful to assign the products in Figure 1 . These products correspond to glyoxylic acid detected as its anion $(m / z 73)$, crotonic acid $(m / z 85)$ or an isomer, such as 4hydroxycrotonaldehyde, 3-oxopropanoic acid $(\mathrm{m} / z \mathrm{87})$, oxalic acid $(m / z 89)$, maleinaldehydic acid $(m / z 99)$, 4-hydroxy-2butenoic acid $(m / z 101)$, 5-oxo-3-pentenoic acid $(m / z 113)$, maleic acid $(\mathrm{m} / z$ 115), 3-hydroxy-o-quinone or 4-hydroxy-oquinone $(\mathrm{m} / \mathrm{z} 123), 1,2,3$ - and 1,2,4-tryhydroxybenzenes $(\mathrm{m} / \mathrm{z}$ $125)$, glutaconic acid $(m / z 129), 3,4$-dihydroxy-o-quinone or 3,6-dihydroxy-o-quinone $(\mathrm{m} / z$ 139), cis,cis-muconic acid and $1,2,3,4-$ and 1,2,4,5-tetrahydroxybenzenes $(\mathrm{m} / z$ 141), 3,4,5tridihydroxy-o-quinone and 3,4,6-tridihydroxy-o-quinone $(\mathrm{m} / \mathrm{z}$ $155)$, pentahydroxybenzene $(m / z 157)$, and hexahydroxybenzene $(m / z 173)$. Scheme 1 shows the proposed routes starting from catechol to form the identified PHA and PHQ products.

Figure 2 shows how the relative ion count of catechol to its initial value $\left(I_{109} / I_{109,0}\right)$ exponentially drops for increasing $\left[\mathrm{O}_{3}(\mathrm{~g})\right]$ in experiments with $1 \leq[$ catechol $] \leq 150 \mu \mathrm{M}$. The behavior observed in Figure 2 agrees with the first-order reaction on both $\left[\mathrm{O}_{3}\right]$ and [catechol] in bulk water. ${ }^{26} \mathrm{O}_{3}(\mathrm{~g})$ molecules diffuse toward the interface, and after the accommodation process, they react with catechol available in the external layer. Catechol loss at the interface is quickly replenished by diffusion of the molecule from its internal reservoir in the core of the microdroplets. The heterogeneous reactions take place within the contact time $\tau_{c} \approx 1 \mu \mathrm{s}$ on a nanoscopic interface of thickness $\delta \approx 1 \mathrm{~nm}$, as observed also for the reaction of $\mathrm{O}_{3}$ with iodide. ${ }^{19}$ The surface density of $\mathrm{O}_{3}$ molecules in the interface, $S_{\mathrm{O}_{3}}$, can be estimated from the dissolved $\left[\mathrm{O}_{3}\right]$ in the thin interfacial slab using eq 1

$$
S_{\mathrm{O}_{3}}=\delta\left[\mathrm{O}_{3}\right]=v_{\mathrm{O}_{3}} \tau_{c} \gamma_{\mathrm{O}_{3}}\left[\mathrm{O}_{3}(\mathrm{~g})\right] / 4
$$

where $v_{\mathrm{O}_{3}}=3.94 \times 10^{4} \mathrm{~cm} \mathrm{~s}^{-1}$ is the mean thermal velocity of $\mathrm{O}_{3}(\mathrm{~g})$ at $298 \mathrm{~K},\left[\mathrm{O}_{3}(\mathrm{~g})\right]$ is the concentration of ozone molecules striking the liquid microdroplets of diameter $D=10$ $\mu \mathrm{m}$ with $\tau_{\mathrm{c}}=1 \times 10^{-6} \mathrm{~s}$, and $\gamma_{\mathrm{O}_{3}}$ is the uptake coefficient of $\mathrm{O}_{3}(\mathrm{~g})$ in water. The dimensionless Henry's law constant, $\mathrm{H}_{0, \mathrm{O}_{3}}$ $=0.269$ (at $298 \mathrm{~K}),{ }^{27}$ can be used to evaluate the reactive uptake coefficient of the gas, $\gamma_{\mathrm{O}_{3}}=\left(4 \delta H_{0}\right) /\left(v_{\mathrm{O}_{3}} \tau_{\mathrm{c}}\right)=2.73 \times$ $10^{-6}$. This $\gamma_{\mathrm{O}_{3}}$ value is 20 times smaller than the maximum measured for solid films of catechol exposed to $\mathrm{O}_{3}(\mathrm{~g})$ at $81 \%$ $\mathrm{RH}^{15}$ Complete $\mathrm{O}_{3}(\mathrm{~g})$ dissolution occurs on the thin interfacial slab faster than $\tau_{\mathrm{c}}$ for all $\left[\mathrm{O}_{3}(\mathrm{~g})\right]$ employed. Diffusion-controlled limitations can be neglected because $I_{109} / I_{109,0}$ in Figure 2 levels off due to the few nanoseconds needed by the solute to diffuse through the $\delta=1 \mathrm{~nm}$ interface and to establish stationary conditions $(\mathrm{d}[$ catechol $] / \mathrm{d} t=0)$ in the open reactor that continuously replenishes the reagent after it reacts with $\mathrm{O}_{3} \cdot{ }^{19,28,29}$

Reactivity Driven by Hydroxyl Radicals. The thermodynamically favorable $(\Delta E=+0.48 \mathrm{~V})$ electron transfer reaction R1 (Scheme 1) between catecholate and dissolved $\mathrm{O}_{3}$, with redox potentials $E_{\text {cathechol }}=0.53 \mathrm{~V}$ and $E_{\mathrm{O}_{3}}=1.01 \mathrm{~V}$ (at $\mathrm{pH} 7)$, produces a semiquinone radical $\left(\mathrm{p} K_{\mathrm{a}}=5\right)^{30}$ directly. ${ }^{31}$ The same reaction can proceed indirectly from molecular catechol through reaction $\mathrm{R} 2$ after the very acidic radical cation $\left(\mathrm{p} K_{\mathrm{a}}=-1.62\right)^{32}$ formed deprotonates in picoseconds. The ozonide radical $\mathrm{O}_{3}{ }^{\bullet-}$ coexists in equilibrium $\mathrm{R} 3\left(K_{\text {eq }}=5.5 \times\right.$ $10^{-7} \mathrm{M}$ at $\left.20^{\circ} \mathrm{C}\right)^{33}$ with the strong base $\mathrm{O}^{-}\left(\mathrm{pK} K_{\mathrm{a}}=11.8\right){ }^{33}$ Therefore, at $\mathrm{pH} \leq 10.8, \mathrm{O}^{--}$is present as its fully associated conjugated acid (equilibrium R4) $\mathrm{HO}^{\bullet}$. Accordingly, it is important to consider how this in-situ-generated $\mathrm{HO}^{\bullet}$ can contribute to the initial degradation of catechol and other phenols/polyphenols in aerosols and at other environmental interfaces, such as the sea surface microlayer of the ocean.

Experiments with catechol at $\mathrm{pH} 10$ provide important information to rationalize the two mechanisms of formation of $o$-semiquinone radicals: (1) from reactions $\mathrm{R} 1$ and $\mathrm{R} 2$ and (2) from the resonance stabilized 1,2,3- or 1,2,4-trihydroxycyclohexadienyl radical formed by $\mathrm{R} 5$ after fast base-catalyzed water elimination via reactions $\mathrm{R} 6$ and $\mathrm{R} 7$. The dehydration reaction of related dihydroxycyclohexadienyl radicals $\left(k^{\prime} \sim 10^{9} \mathrm{M}^{-1} \mathrm{~s}^{-1}\right)$ can only compete with the fast addition of $\mathrm{O}_{2}$ to the dihydroxycyclohexadienyl radicals under acid or base catalysis. ${ }^{34}$ Therefore, the base-catalyzed dehydration of trihydroxycyclohexadienyl radicals by reactions $\mathrm{R} 6$ and $\mathrm{R} 7^{35}$ competes with the production of trihydroxycyclohexadienyl peroxy radicals by reactions $\mathrm{R} 8$ and $\mathrm{R} 9$ (also, $k \sim 10^{9} \mathrm{M}^{-1} \mathrm{~s}^{-1}$ ) 35 at $\mathrm{pH} 10$ (see Figure $\mathrm{S} 1$ of the Supporting Information). Considering the partial pressure of oxygen in the system, $P_{\mathrm{O}_{2}}$ $=0.01639 \mathrm{~atm}\left(\mathrm{H}_{0, \mathrm{O}_{2}}=0.0013 \mathrm{M}\right.$ atm $^{-1}$ at $\left.25{ }^{\circ} \mathrm{C}\right),{ }^{27}$ there is $\left[\mathrm{O}_{2}\right]=21.3 \mu \mathrm{M}$ under equilibrium conditions to compete for the intermediate.

Under pH 5 (see Figure S1 of the Supporting Information), catechol appears to be relatively stable during the microsecond 
Scheme 1. Proposed Oxidation Mechanism of Catechol by Hydroxyl Radicals at the Air-Water Interface ${ }^{a}$

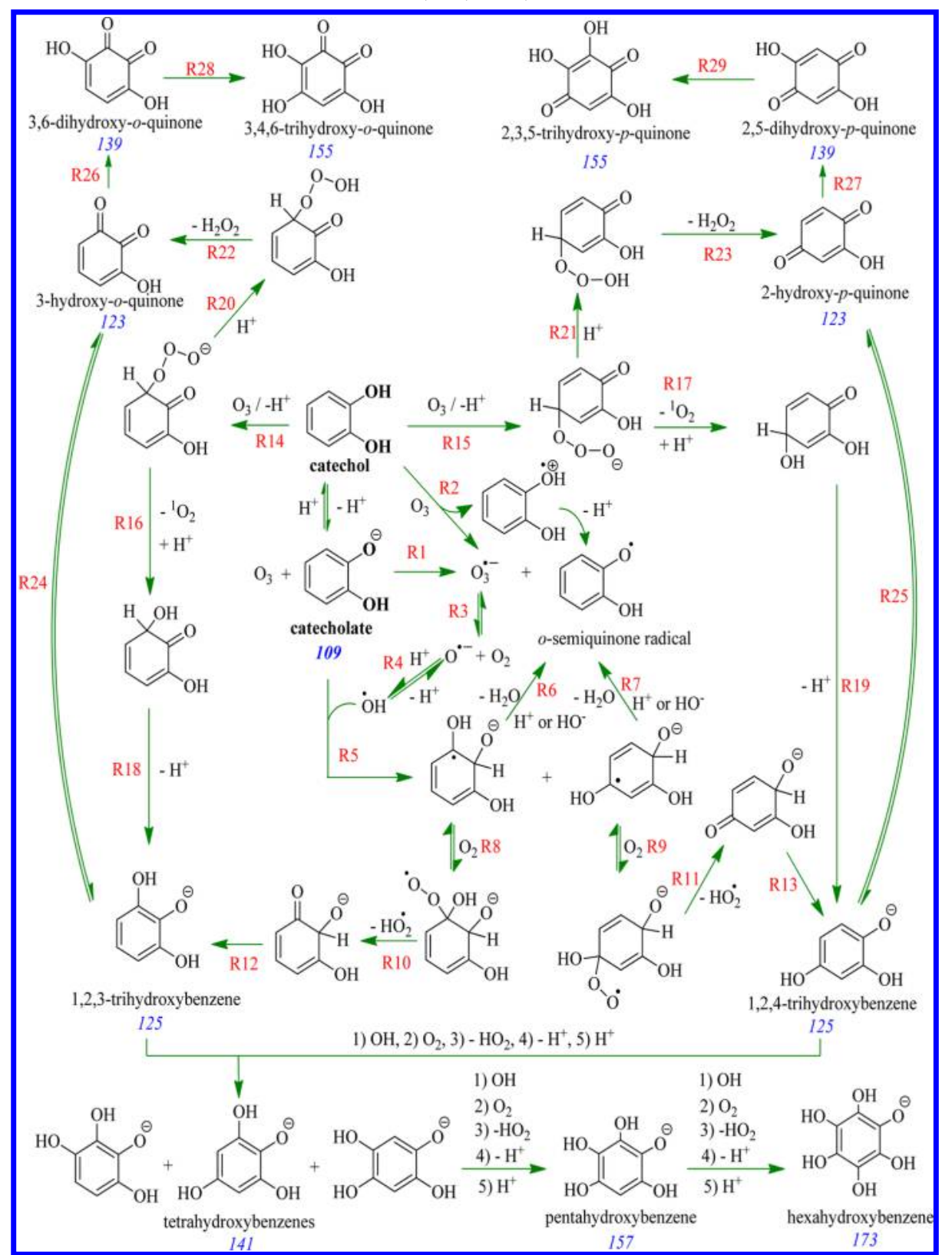

${ }^{a}$ Reaction numbers and observed $\mathrm{m} / z$ values are given in red and blue fonts, respectively.

contact time. However, for the $\mathrm{pH}$ interval from 6 to 9 , the formation of products at $\mathrm{m} / z 123$ (hydroxyquinones), 125 (trihydroxybenzenes), 139 (dihydroxyquinones), and 141 (trihydroxybenzenes) is observed. The results of this study show that the complexity of the heterogeneous ozonolysis of catechol at neutral and even slightly basic or acidic $\mathrm{pH}$ is higher than previously considered. ${ }^{15}$ Figure 3 displays how the main products observed for the loss of catechol $\left(\mathrm{p} K_{\mathrm{a} 1}=9.34\right.$, and $\mathrm{pK}_{\mathrm{a} 2}=12.60$, at $\left.298 \mathrm{~K}\right)^{23}$ change with $\left[\mathrm{O}_{3}(\mathrm{~g})\right]$. The fast production of $\mathrm{HO}^{\bullet}$ is evidenced by the quick appearance of 1,2,3- and/or 1,2,4-trihydroxybenzenes $\left(I_{125}\right)$ during the interfacial ozonolysis of $1 \leq$ [catechol] $\leq 150 \mu \mathrm{M}$ (Figure $3 \mathrm{~A})$. The maximum value of $I_{125}$ is reached at $626 \mathrm{ppbv} \mathrm{O}_{3}(\mathrm{~g})$ for the electrophilic addition of $\mathrm{HO}^{\bullet}$ to the ortho and para positions of catechol via $\mathrm{R} 5+\mathrm{R} 8+\mathrm{R} 10+\mathrm{R} 12$ and $\mathrm{R} 5+\mathrm{R} 9+$
$\mathrm{R} 11+\mathrm{R} 13$, respectively. For higher $\left[\mathrm{O}_{3}(\mathrm{~g})\right], I_{125}$ decays smoothly because of its conversion into other products.

Figure 3 also shows that trihydroxybenzene signals grow faster than for all other species and dominate the products at the low $\left[\mathrm{O}_{3}(\mathrm{~g})\right]$ for the $\mathrm{pH}$ range in which $\mathrm{HO}^{\bullet}$ is quickly produced. Even under acidic conditions of $\mathrm{pH} \mathrm{6}$, the production of trihydroxybenzenes is observed and starts vanishing for $\mathrm{pH} \leq 5$ (see Figure $\mathrm{S} 1$ of the Supporting Information). Acid and base catalysis should promote reactions $\mathrm{R} 6$ and $\mathrm{R} 7$, but at $\mathrm{pH} \mathrm{7,} \mathrm{the} \mathrm{addition} \mathrm{of} \mathrm{superoxide} \mathrm{radicals}$ (introduced below), $\mathrm{O}_{2}{ }^{\bullet-}$, to the trihydroxycyclohexadienyl radicals would stop the production of trihydroxybenzenes. The reactivity of 1,2,3- or 1,2,4-trihydroxycyclohexadienyl radicals toward abundant $\mathrm{O}_{2}(\mathrm{~g})$ to produce $1,2,3-$ and $1,2,4-$ trihydroxybenzenes simultaneously results in the release of hydroperoxyl radicals $\mathrm{HO}_{2}{ }^{\bullet}$ during $\mathrm{R} 10$ and R11. The 


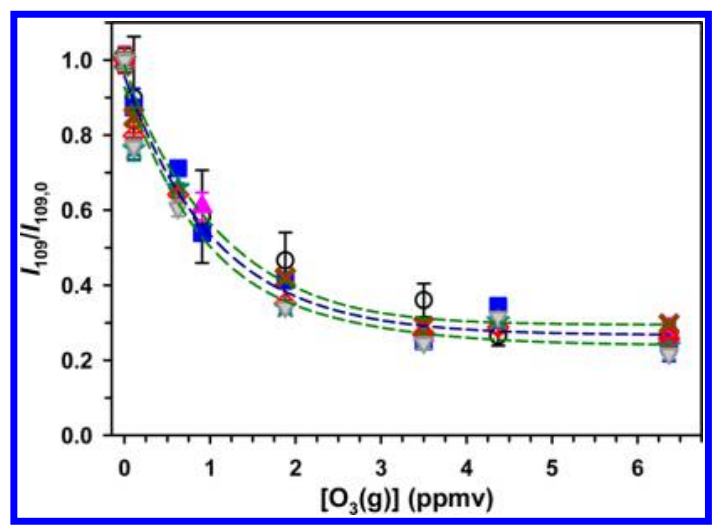

Figure 2. Relative ion count of catechol $(\mathrm{m} / z 109)$ to its initial value, $I_{109} / I_{109,0}$, in the ESI mass spectra for aerosolized solutions of $[\text { catechol }]_{0}=1 \mu \mathrm{M}$ (open black circle), $10 \mu \mathrm{M}$ (blue square), $25 \mu \mathrm{M}$ (pink triangle), $50 \mu \mathrm{M}$ (brown cross), $100 \mu \mathrm{M}$ (teal blue star), 125 $\mu \mathrm{M}$ (red open diamond), and $150 \mu \mathrm{M}$ (gray inverted triangle) as a function of increasing $\left[\mathrm{O}_{3}(\mathrm{~g})\right]$ at $\mathrm{pH}$ 7.8. The overall nonlinear regression (dashed blue trace) with a $95 \%$ confidence interval (dashed green traces) decays exponentially as $I_{109} / I_{109,0}=0.267+$ $0.690 e^{-0.948[\text { catechol }]}$, with $r^{2}=0.971$.

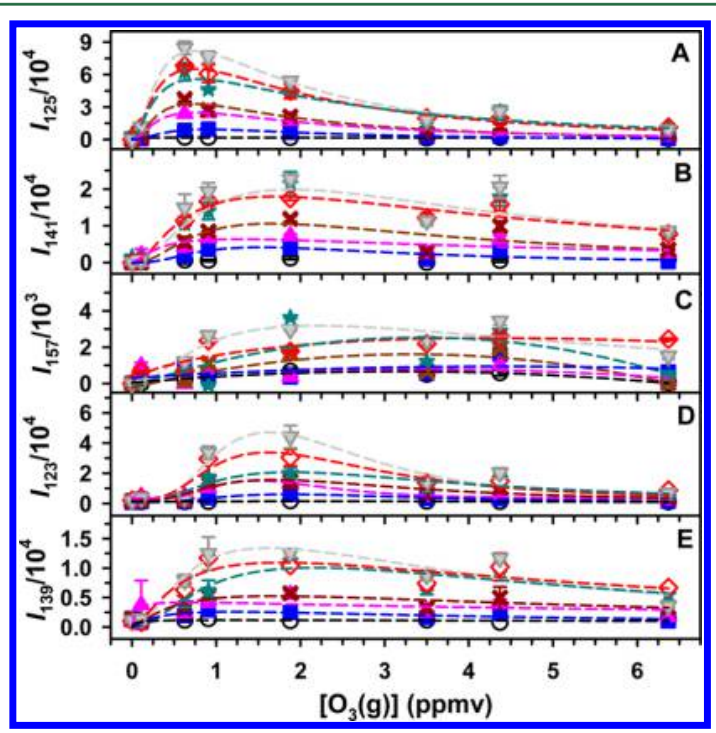

Figure 3. Ion count, $I_{m / z}$, of (A) 1,2,3- and 1,2,4-trihydroxybenzenes $(m / z 125)$, (B) cis,cis-muconic acid and $1,2,3,4-$ and $1,2,4,5$ tetrahydroxybenzenes $(\mathrm{m} / \mathrm{z} 141),(\mathrm{C})$ pentahydroxybenzene $(\mathrm{m} / \mathrm{z}$ 157), (D) 3-hydroxy- and 4-hydroxy-o-quinones $(\mathrm{m} / z \mathrm{123})$, and (E) 3,4-dihydroxy- and 3,6-dihydroxy-o-quinones $(\mathrm{m} / z$ 139) produced from exposing aerosolized catechol solutions in Figure $2 \mathrm{~A}$ to increasing $\left[\mathrm{O}_{3}(\mathrm{~g})\right]$.

equilibrium between conjugated $\mathrm{HO}_{2}{ }^{\bullet}$ acid $\left(\mathrm{p} K_{\mathrm{a}}=4.8\right)^{36}$ and superoxide radical $\mathrm{O}_{2}{ }^{-}$is shifted toward the formation of the dissociated species in these experiment.

In principle, the reaction $\mathrm{O}_{2}{ }^{--}+\mathrm{O}_{3} \rightleftharpoons \mathrm{O}_{3}{ }^{--}+\mathrm{O}_{2}\left(k_{\mathrm{O}_{2}}{ }^{--}+\mathrm{O}_{3}\right.$ $\left.=1.5 \times 10^{9} \mathrm{M}^{-1} \mathrm{~s}^{-1}\right)^{37}$ can produce $\mathrm{O}_{3}^{\cdot-}$, which regenerates $\mathrm{HO}{ }^{\bullet}$ through reactions $\mathrm{R} 3+\mathrm{R} 4 .{ }^{37}$ Nevertheless, the recycling of $\mathrm{O}_{2}{ }^{\bullet-}$ should be unimportant at high $\mathrm{pH}$, as explained next. Although the rate constant for the reaction of catecholate with $\mathrm{O}_{3}$ is unknown, it should be in the order of typical diffusioncontrolled reactions under present conditions $\left(k_{\mathrm{O}_{3}}+\right.$ catecholate $\simeq$ $\left.10^{10} \mathrm{M}^{-1} \mathrm{~s}^{-1}\right)$. Therefore, considering that [catecholate] $\gg$ $\left[\mathrm{O}_{2}{ }^{-}\right.$], the rate of reaction $\mathrm{R} 1$ is orders of magnitude larger than the rate of reaction of $\mathrm{O}_{2}{ }^{-1}$ with $\mathrm{O}_{3}{ }^{38}$ rate $R_{1} \gg$ rate $R_{\mathrm{O}_{2}} \cdot-+\mathrm{O}_{3}$

$k_{\mathrm{O}_{3}+\text { catecholate }}[$ catecholate $]\left[\mathrm{O}_{3}\right] \gg k_{\left.\mathrm{O}_{2} \cdot{ }^{-}+\mathrm{O}_{3}\right)}\left[\mathrm{O}_{2}^{\bullet-}\right]\left[\mathrm{O}_{3}\right]$

$\sim 10^{10} \mathrm{M}^{-1} \mathrm{~s}^{-1}\left[\right.$ catecholate] $\left[\mathrm{O}_{3}\right]$

$\gg 1.5 \times 10^{9} \mathrm{M}^{-1} \mathrm{~s}^{-1}\left[\mathrm{O}_{2}^{\bullet-}\right]\left[\mathrm{O}_{3}\right]$

For example, for [catechol] $=25 \mu \mathrm{M}$ at $\mathrm{pH} 10\left(\alpha_{\mathrm{C}_{6} \mathrm{H}_{4}(\mathrm{OH}) \mathrm{O}^{-}}=\right.$ $81.9 \%)$, catecholate scavenges the interfacial $\mathrm{O}_{3}{ }^{19}$ by reaction $\mathrm{R} 1$ more efficiently than the much less abundant $\mathrm{O}_{2}{ }^{-}$, , making the superoxide radical pathway for indirect $\mathrm{HO}^{\bullet}$ production negligible. In addition to the indirect oxidation of catechol with $\mathrm{HO}^{\bullet}$ described above, Scheme 1 includes other channels for the production of 1,2,3- and 1,2,4-trihydroxybenzenes $(\mathrm{m} / \mathrm{z} 125)$, presented in Figure 3A. The direct attack of $\mathrm{O}_{3}$ to positions 3 and 6 of catechol to produce 1,2,3- and 1,2,4-trihydroxybenzenes should proceed with the release of $\mathrm{O}_{2}\left({ }^{1} \Delta_{\mathrm{g}}\right)$ through reactions $\mathrm{R} 14+\mathrm{R} 16+\mathrm{R} 18$ and $\mathrm{R} 15+\mathrm{R} 17+\mathrm{R} 19$, respectively. ${ }^{39}$ Chemiluminescent emissions of the hydroxytrioxide anion intermediates by R16 and R17 were observed during the ozonolysis of catechol. ${ }^{40}$

The net increase of $I_{141}$ in Figure 3B remains lower than $I_{125}$ and reaches a maximum at $1.88 \mathrm{ppmv} \mathrm{O}_{3}(\mathrm{~g})$. Because $I_{125}>$ $I_{141}$, the results at low $\left[\mathrm{O}_{3}(\mathrm{~g})\right]$ strongly suggest that $1,2,3$ - and 1,2,4-trihydroxybenzenes are produced earlier than the species at $\mathrm{m} / z$ 141. In addition, the tetrahydroxybenzene products should decay faster than the trihydroxybenzenes precursors because they are more prone to undergo further oxidation. However, the sequential conversion of the ozonide of catechol into a hydroperoxide intermediate results in the generation of cis,cis-muconic acid, as reported in bulk water. ${ }^{20}$ cis,cis-Muconic acid also contributes to the signal at $m / z$ 141, a product discussed below in terms of the direct cleavage of catechol. The same mechanistic steps producing trihydroxybenzenes from catechol are invoked at the bottom of Scheme 1 to explain the generation of tetrahydroxybenzenes $(\mathrm{m} / z 141)$ from trihydroxybenzenes, pentahydroxybenzene $(m / z 157$; Figure $3 C)$ from tetrahydroxybenzenes, and hexahydroxybenzene from pentahydroxybenzene. In Figure 3C, $I_{157}$ reaches a plateau for $\left[\mathrm{O}_{3}(\mathrm{~g})\right]$ $=880 \mathrm{ppbv}$, indicating steady-state conditions for these species assigned to 1,2,3,4-, 1,2,3,5-, and 1,2,4,5-tetrahydroxybenzenes in Scheme 1.

Figure 3D shows the production of 3-hydroxy-o-quinone and/or 2-hydroxy-p-quinone $\left(I_{123}\right)$. These species can be easily produced from (1) the action of semiquinone radicals and (2) the elimination of $\mathrm{H}_{2} \mathrm{O}_{2}$ after $\mathrm{O}_{3}$ attack to positions 3 and 4 of catechol. In the first case, the corresponding 1,2,3- and 1,2,4tryhydroxybenzenes generated from 1,3 and 1,4 addition of ozone to catechol react directly with the in-situ-formed $o$ semiquinone radical to generate 3-hydroxy-o-quinone and 2hydroxy-p-quinone, respectively. Because the participation of the $o$-semiquinone radical that regenerates catechol seems less likely to contribute to the formation of quinones than the pathways from $\mathrm{H}_{2} \mathrm{O}_{2}$ elimination, the former reactions are only depicted in Scheme S1 of the Supporting Information. These reactions could proceed through a cyclic ozonide intermediate. Although the reaction was studied for phenol, the several steps involved are complex and no complete mechanistic understanding was yet reached. ${ }^{38}$ In the second case, the production of 3-hydroxy-o-quinone and/or 2-hydroxy-p-quinone is given 
Scheme 2. Proposed Mechanism for the Direct Ozonolysis of Catechol at the Air-Water Interface ${ }^{a}$

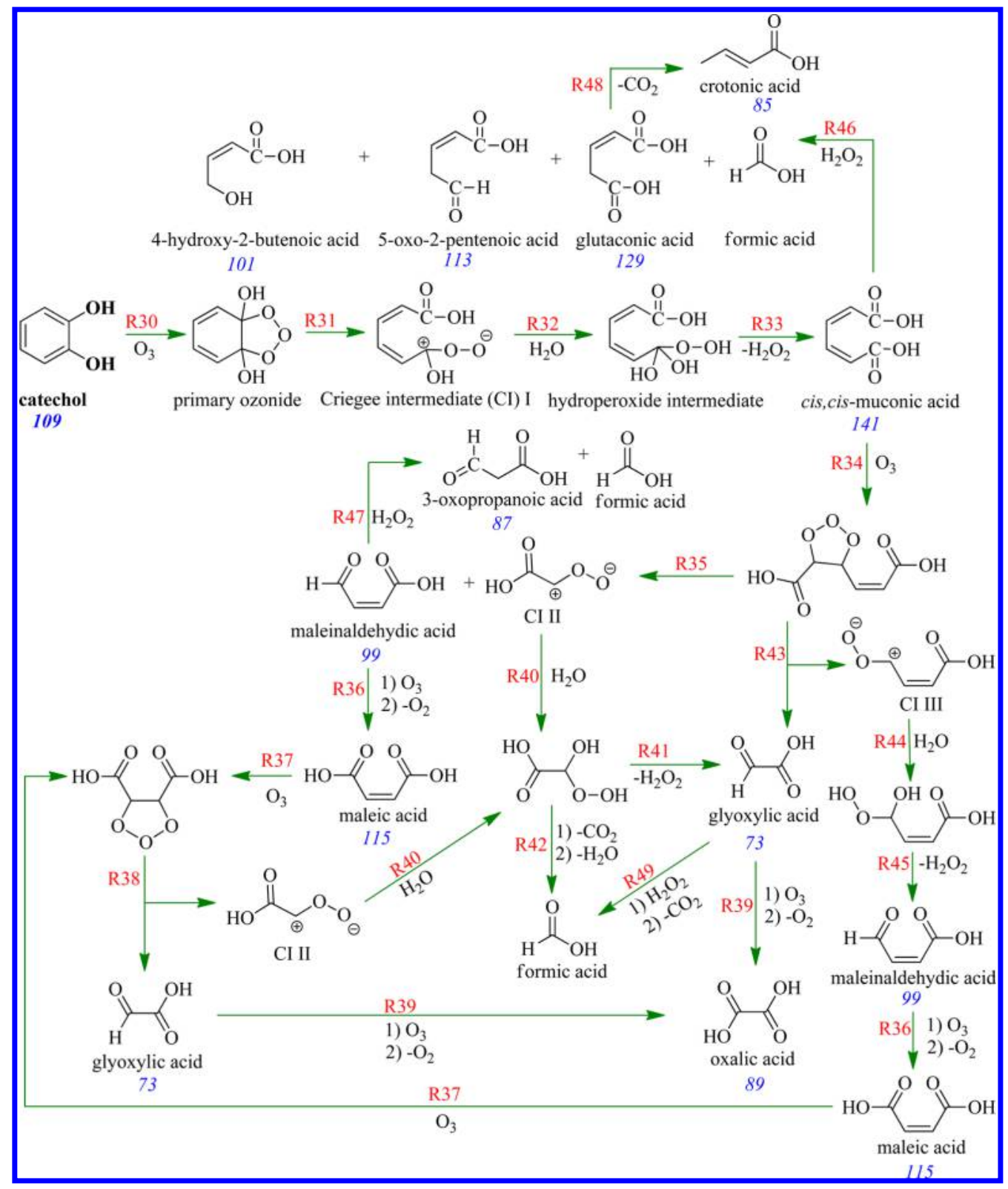

${ }^{a}$ Reaction numbers and observed $\mathrm{m} / z$ values are given in red and blue fonts, respectively.

by the sequences $\mathrm{R} 14+\mathrm{R} 20+\mathrm{R} 22$ and $\mathrm{R} 15+\mathrm{R} 21+\mathrm{R} 23$, respectively.

Theoretically, the disproportionation of two semiquinone radicals of the hydroxyquinones may interconvert the species with $\mathrm{m} / z 125$ and 123 via R24 and R25 (Scheme 1), although its probability seems low because it depends upon the encounter of two such radicals at the interface of short-lived droplets. The $\mathrm{pH}$ dependence for $\mathrm{R} 25$, the fast redox conversion of 1,2,4-trihydroxybenzene to 2-hydroxy-p-quinone in bulk water, is provided in Figure S2 of the Supporting Information and has also been observed during studies of denitrifying bacteria. ${ }^{41}$

Figure 3E presents the production of isomers, such as 3,6dihydroxy-o-quinone and 2,5-dihydroxy-p-quinone, with $\mathrm{m} / \mathrm{z}$ 139, which may be produced in reactions R26 and R27 by hydroxylation of 3-hydroxy-o-quinone and 2-hydroxy-p-quinone, respectively. The interconversion of quinone $(\mathrm{m} / z 123)$ and hydroquinone $(m / z 125)$ redox pair 123:125 described above by R24 and R25 could be considered also for the pairs 139:141 and 155:157, which under typical oxidizing conditions are shifted toward the quinone form. The related production of trihydroxyquinones by R28 and R29 is included in Scheme 1.

In summary, because some catechol is dissociated into catecholate $\left(\alpha_{\mathrm{C}_{6} \mathrm{H}_{4}(\mathrm{OH}) \mathrm{O}^{-}}=4.4 \%\right.$, and $\left.\alpha_{\mathrm{C}_{6} \mathrm{H}_{4}(\mathrm{OH})_{2}}=95.6 \%\right)$ at $\mathrm{pH}$ 8 , a reactive channel with in-situ-generated $\mathrm{HO}^{\bullet}$ radicals enhances the loss of total catechol. ${ }^{31}$ While, at low $\mathrm{pH}$, the electrophilic attack of $\mathrm{O}_{3}$ to catechol dominates the mechanism, radical-radical reactions are also observed at neutral and basic $\mathrm{pH}$ values. At slightly basic $\mathrm{pH}$ and even at $\mathrm{pH} 7$, hydroxyl radicals become a considerable oxidizing agent that simultaneously attacks the ring of catechol. The rate constant for the reaction of aqueous catechol with $\mathrm{HO}^{-}$(measured at $\mathrm{pH}$ 9), $k_{\mathrm{HO}}{ }^{\circ}$ catechol $=1.1 \times 10^{10} \mathrm{M}^{-1} \mathrm{~s}^{-1}, 42$ is $2 \times 10^{4}$ times larger than that for its reaction with $\mathrm{O}_{3}, k_{\mathrm{O}_{3}}+$ catechol $=5.2 \times 10^{5} \mathrm{M}^{-1} \mathrm{~s}^{-1}$ 
(available only at $\mathrm{pH} 7$ ). ${ }^{38}$ Because the rate of $\mathrm{HO}^{\bullet}$ production increases for higher $\mathrm{pH}$ values, the loss of catechol (Figure 2) and the generation of products (Figure 3 ) includes contributions from both $\mathrm{O}_{3}$ and $\mathrm{HO}^{\bullet}$ oxidizing agents. However, the rate of catechol loss should not be described with typical bulk kinetics ${ }^{26}$ but by a Langmuir-Hinshelwood mechanism $^{43}$ that considers the adsorption isotherms of the oxidizers. ${ }^{16}$ The reactive uptake coefficients of $\mathrm{O}_{3}(\mathrm{~g})\left(\gamma_{\mathrm{O}_{3}}=\right.$ $2.73 \times 10^{-6}$ estimated herein) and $\mathrm{OH}$ radical $\left(\gamma_{\mathrm{OH}}\right.$ is unavailable) on catechol at the air-water interface should be considered to account for the number of collisions leading to reaction. Because for species, such as 4-methyl-5-nitrocatechol and levoglucosan, $\gamma_{\mathrm{OH}}>10^{-2}, 44$ it is expected that $\gamma_{\mathrm{OH}} \gg \gamma_{\mathrm{O}_{3}}$ for catechol.

Direct Oxidation Reaction Driven by Ozone. In the previous discussion of Figure 1, several multifunctional carboxylic acids were listed but the mechanism to account for their generation differs from that presented in Scheme 1. The generation of glyoxylic acid $(m / z 73)$, crotonic acid $(m / z 85)$, 3-oxopropanoic acid $(m / z 87)$, oxalic acid $(m / z 89)$, maleinaldehydic acid $(\mathrm{m} / z$ 99), 4-hydroxy-2-butenoic acid $(\mathrm{m} / z$ 101), 5-oxo-2-pentenoic acid $(\mathrm{m} / z$ 113), maleic acid $(\mathrm{m} /$ $z 115)$, glutaconic acid $(m / z 129)$, and cis,cis-muconic acid $(m /$ $z$ 141) must result from the direct electrophilic attack of ozone to the 1,2 carbon-carbon bond of catechol. The production pathways and $m / z$ values for all species detected are given in red and blue fonts in Scheme 2, respectively. Ring cleavage was proposed to proceed through a phenoxide anion for the related molecule of phenol in water ${ }^{45}$ or through the phenoxide radical produced from the first-order reaction of ozone with the phenoxide anion. ${ }^{46}$ The lower levels of direct ozonolysis products clearly distinguished in Figure 1 are due to the microsecond contact time in the setup, ${ }^{19}$ which does not allow for the accumulation of secondary oxidation products.

Scheme 2 implies that catechol undergoes the electrophilic attack of $\mathrm{O}_{3}$ to the bond between carbons 1 and 2 through a primary ozonide by reaction $\mathrm{R} 30$, forming consecutively the first Criegee intermediate (CI) by R31, a hydroperoxide intermediate by R32, and cis,cis-muconic acid $(\mathrm{m} / z 141)$ after a loss of $\mathrm{H}_{2} \mathrm{O}_{2}$ by $\mathrm{R} 33{ }^{25}$ The production of cis,cis-muconic acid in Scheme 2 should be favored at lower $\mathrm{pH}$, because at higher $\mathrm{pH}$, the channel of $\mathrm{O}_{2}\left({ }^{1} \Delta_{\mathrm{g}}\right)$ elimination by $\mathrm{R} 16$ and $\mathrm{R} 17$ (Scheme 1) is preferred from the stabilized hydroxytrioxide anions generating 1,2,3- and 1,2,4-trihydroxybenzenes at $\mathrm{m} / \mathrm{z}$ 125. In Scheme 2, the unsaturated species cis,cis-muconic acid, the primary product of catechol direct ozonolysis, is further processed to form other organic acids. ${ }^{47}$ The ozonide resulting from R34 can decompose in two different sets of products, (1) maleinaldehydic acid $(\mathrm{m} / z$ 99) and a second Criegee intermediate (CI II) by R35 and (2) glyoxylic acid $(\mathrm{m} / z 73)$ and a third Criegee intermediate (CI III) by R43. The aldehyde group in maleinaldehydic acid is susceptible to ozone attack by R36 and further oxidation to maleic acid $(\mathrm{m} / z$ 115). The oxidation of the unsaturated bond of maleic acid also results in the production of glyoxylic acid and CI II by R37 + R38.

The common oxidative fate of glyoxylic acid (from R38 and R43 in Scheme 2) is oxalic acid $(m / z$ 89) by R39. A hydroperoxide is formed after hydration of CI II by R40, which can yield $\mathrm{H}_{2} \mathrm{O}_{2}$ to the medium, generating also glyoxylic acid by $\mathrm{R} 41$ or decarboxylate into formic acid by R42. A different pathway for the formation of maleinaldehydic acid from CI III by $\mathrm{R} 44+\mathrm{R} 45$ merges with the production of maleic acid by
R36 and glyoxylic acid by R37 + R38. Scheme 2 accounts for the formation of 4-hydroxy-2-butenoic acid $(\mathrm{m} / z$ 101), 5-oxo3-penteneoic acid $(m / z 113)$, and glutaconic acid $(m / z 129)$ by the Baeyer-Villiger (BV) oxidation of cis,cis-muconic acid reaction R46. ${ }^{48}$ Similarly, Scheme 2 also shows the BV oxidation of maleinaldehydic acid to 3-oxopropanoic acid $(\mathrm{m} /$ $z 87)$ by R47 and glutaconic acid to crotonic acid $(\mathrm{m} / z 87)$ or an isomer after decarboxylation via R48.

The results of spiked analysis with standards and deconvolution of $45 \%$ of $I_{141}$ arising from $25 \mu \mathrm{M}$ cis,cismuconic acid exposed to $3.18 \mathrm{ppmv}_{3}(\mathrm{~g})$ at $\mathrm{pH} 8$ are provided in Figure $\mathrm{S} 1$ of the Supporting Information. On the basis of this specific case, the predominant products of interfacial ozonolysis depicted in Scheme 2 are [glyoxylic acid $]=200 \mathrm{nM}>$ [oxalic acid $]=174 \mathrm{nM}>$ [cis,cis-muconic acid $]=129 \mathrm{nM}>$ [3-oxopropanoic acid] $=109 \mathrm{nM}$. Some reaction products (e.g., the dicarbonyl species glyoxal, $\mathrm{CO}_{2}$, and $\left.\mathrm{H}_{2} \mathrm{O}_{2}\right)^{25}$ remain undetected by this technique. In this regard, the support for $\mathrm{BV}$-promoted reactions ${ }^{48}$ from generated $\mathrm{H}_{2} \mathrm{O}_{2}{ }^{49}$ arises from the in situ oxidation of products that result in glyoxylic acid by R49. ${ }^{50}$ The latter reaction resulting in formic acid involves ozone attack to a double bond conjugated to a carbonyl. Considering that glyoxylic acid generates $\mathrm{CO}_{2}$ and formic acid, it is reasonable to propose that maleinaldehydic, glutaconic, and cis,cis-muconic acids could be the precursor of peaks at $m / z 85,87,101,113$, and 129 in Figure 1 , as indicated in Scheme 2.

Atmospheric Implications. Catechol undergoes fast oxidation at the air-water interface by several competing pathways. Hydroxylation and cleavage of the aromatic ring of catechol occur at the air-water interface. The initial oxidation reaction of polyphenols is governed by $\mathrm{HO}^{\bullet}$ radicals formed at high yields under atmospheric conditions. The rate constant for the reaction of catechol with $\mathrm{HO}^{\bullet}$ in the gas phase under dry conditions is $k_{\text {catechol }+\mathrm{HO}}=1.04 \times 10^{-10} \mathrm{~cm}^{3}$ molecules $^{-1} \mathrm{~s}^{-1} .51$ For an average tropospheric $\left[\mathrm{HO}^{\circ}\right]=1.6 \times 10^{6}$ radicals cm ${ }^{-3}, 52$ the residence time $\left.\left(\tau_{i}=k^{-1} \text { [oxidizer }\right]^{-1}\right)$ of catechol against $\mathrm{HO}^{\circ}$ is $\tau_{\text {catechol }+\mathrm{HO}}=1.7 \mathrm{~h}$. The rate constant of catechol reacting with $\mathrm{O}_{3}(\mathrm{~g})$ on the surface of $\mathrm{NaCl}$ at $\mathrm{RH}=2 \%$ is $k_{\text {catechol }+\mathrm{O}_{3}}^{\mathrm{NaCl}}=6.3 \times 10^{-17} \mathrm{~cm}^{3}$ molecule ${ }^{-1} \mathrm{~s}^{-1} \cdot{ }^{16}$ Assuming standard pressure and 40 ppbv $\mathrm{O}_{3}(\mathrm{~g}) \equiv\left[\mathrm{O}_{3}(\mathrm{~g})\right]=9.85 \times 10^{11}$ molecules $\mathrm{cm}^{-3}$, the residence time against loss by ozone is $\tau_{\text {catechol }+\mathrm{O}_{3}}=4.5 \mathrm{~h}$, which is 6.9 times shorter than in the gas phase. ${ }^{51}$ A $27 \%$ of the total loss of catechol can be contributed by heterogeneous ozonolysis to a mechanism that is largely dominated by gas-phase $\mathrm{HO}^{\bullet}$ during daytime.

A simple analysis can assess the importance of gaseous $\mathrm{O}_{3}$ and $\mathrm{OH}$ interfacial driven chemistry under time scales shorter than the residence time of catechol against both oxidizers. This analysis considers that the same particle, i.e., the same surface (A) of a $100 \mathrm{~nm}$ diameter particle covered by catechol molecules, reacts with $\mathrm{O}_{3}(\mathrm{~g})$ or $\mathrm{OH}(\mathrm{g})$. The ratio for the rate of loss of molecules by $\left[\mathrm{O}_{3}(\mathrm{~g})\right]=9.85 \times 10^{11}$ molecules $\mathrm{cm}^{-3}$ and $[\mathrm{OH}(\mathrm{g})]=1.6 \times 10^{6}$ molecules $\mathrm{cm}^{-3}$ can be bracketed in the particle using the kinetic theory of gases ${ }^{53}$

$$
1 \leq\left(\gamma_{\mathrm{O}_{3}}\left[\mathrm{O}_{3}(\mathrm{~g})\right] v_{\mathrm{O}_{3}} A / 4\right) /\left(\gamma_{\mathrm{OH}}[\mathrm{OH}(\mathrm{g})] v_{\mathrm{OH}} A / 4\right) \leq 100
$$

where room temperature is assumed, $\gamma_{\mathrm{O}_{3}}=2.73 \times 10^{-6}, 0.01<$ $\gamma_{\mathrm{OH}}<1$, and the mean thermal velocity of $\mathrm{OH}$ radicals is $v_{\mathrm{OH}}=$ $6.61 \times 10^{4} \mathrm{~cm} \mathrm{~s}^{-1}$. Therefore, this comparison suggests that the loss of catechol by $\mathrm{O}_{3}$ may be up to 100 times faster than for 
$\mathrm{OH}$ radicals during interfacial reactions. However, because this analysis did not consider the interfacial production of $\mathrm{OH}$ radicals reported in this work, future research should try to assess the contribution from in-situ-produced radicals to the loss of catechol.

Hydroxylation contributes to enhance the reactivity of biomass-burning emissions toward atmospheric oxidants as well as the absorptivity ${ }^{54-56}$ of airborne species. After the initial processing of aromatic species by abundant $\mathrm{HO}^{\bullet}$, direct ozonolysis becomes a competitive mechanism for the loss of produced PHA and chromophoric PHQ compounds at the air-water interface. Considering the shorter $\tau_{\text {catechol }+\mathrm{OH}}$ and $\tau_{\text {catechol }+\mathrm{O}_{3}}$ than the residence time of biomass-burning plumes and tropospheric aerosols against deposition $(\sim 1$ week $),{ }^{52}$ the mechanisms described contribute to the aging of particles during transport. Moreover, the chain of oxidation reactions generates low-molecular-weight (LMW) oxo- and unsaturated dicarboxylic acids, precursors to tropospheric HULIS. ${ }^{22}$ This work provides a plausible explanation to the mechanisms by which high levels of dicarbonyls and oxo- and dicarboxylic acids are produced in aerosols ${ }^{7-10}$ from biomass-burning products. $^{11,12}$ The mechanisms have direct global implication because they provide new pathways for aqueous SOA (AqSOA) formation of brown carbon species with low volatility. ${ }^{57}$

\section{ASSOCIATED CONTENT}

\section{S Supporting Information}

Additional results, Figures S1-S5, Tables S1 and S2, and Scheme S1. This material is available free of charge via the Internet at http://pubs.acs.org.

\section{AUTHOR INFORMATION}

\section{Corresponding Author}

*Telephone: 859-323-2892. Fax: 859-323-9985. E-mail: marcelo.guzman@uky.edu.

\section{Notes}

The authors declare no competing financial interest.

\section{ACKNOWLEDGMENTS}

The authors thank research funding from the National Aeronautics and Space Administration (NASA) (NNX10AV39A) and the National Science Foundation (NSF) CAREER Award (CHE-1255290).

\section{REFERENCES}

(1) Boucher, O.; Randall, D.; Artaxo, P.; Bretherton, C.; Feingold, G.; Forster, P.; Kerminen, V.-M.; Kondo, Y.; Liao, H.; Lohmann, U.; Rasch, P.; Satheesh, S. K.; Sherwood, S.; Stevens, B.; Zhang, X.-y.; Fuzzi, S.; Penner, J. E.; Ramaswamy, V.; Stubenrauch, C. Clouds and aerosols. In Climate Change 2013: The Physical Science Basis. Contribution of Working Group I to the Fifth Assessment Report of the Intergovernmental Panel on Climate Change; Stocker, T. F., Qin, D., Plattner, G.-K., Tignor, M., Allen, S. K., Boschung, J., Nauels, A., Xia, Y., Bex, V., Midgley, P. M., Eds.; Cambridge University Press: New York, NY, 2013.

(2) Hallquist, M.; Wenger, J. C.; Baltensperger, U.; Rudich, Y.; Simpson, D.; Claeys, M.; Dommen, J.; Donahue, N. M.; George, C.; Goldstein, A. H.; Hamilton, J. F.; Herrmann, H.; Hoffmann, T.; Iinuma, Y.; Jang, M.; Jenkin, M. E.; Jimenez, J. L.; Kiendler-Scharr, A.; Maenhaut, W.; McFiggans, G.; Mentel, Th. F.; Monod, A.; Prévôt, A. S. H.; Seinfeld, J. H.; Surratt, J. D.; Szmigielski, R.; Wildt, J. The formation, properties and impact of secondary organic aerosol:
Current and emerging issues. Atmos. Chem. Phys. 2009, 9 (14), $5155-5236$.

(3) Finlayson-Pitts, B. J. Reactions at surfaces in the atmosphere: integration of experiments and theory as necessary (but not necessarily sufficient) for predicting the physical chemistry of aerosols. Phvs. Chem. Chem. Phvs. 2009, 11 (36), 7760-7779.

(4) Rudich, Y.; Donahue, N. M.; Mentel, T. F. Aging of organic aerosol: Bridging the gap between laboratory and field studies. Annu. Rev. Phvs. Chem. 2007, 58 (1), 321-352.

(5) Mkoma, S. L.; Kawamura, K. Molecular composition of dicarboxylic acids, ketocarboxylic acids, $\alpha$-dicarbonyls and fatty acids in atmospheric aerosols from Tanzania, East Africa during wet and dry seasons. Atmos. Chem. Phvs. 2013, 13 (4), 2235-2251.

(6) Fu, P.; Kawamura, K.; Usukura, K.; Miura, K. Dicarboxylic acids, ketocarboxylic acids and glyoxal in the marine aerosols collected during a round-the-world cruise. Mar. Chem. 2013, 148, 22-32.

(7) Mochida, M.; Kawamura, K.; Umemoto, N.; Kobayashi, M.; Matsunaga, S.; Lim, H. J.; Turpin, B. J.; Bates, T. S.; Simoneit, B. R. T. Spatial distributions of oxygenated organic compounds (dicarboxylic acids, fatty acids, and levoglucosan) in marine aerosols over the western Pacific and off the coast of East Asia: Continental outflow of organic aerosols during the ACE-Asia campaign. L. Geophys. Res.: Atmos. 2003, 108 (D23), 8638.

(8) Kawamura, K.; Tachibana, E.; Okuzawa, K.; Aggarwal, S. G.; Kanaya, Y.; Wang, Z. F. High abundances of water-soluble dicarboxylic acids, ketocarboxylic acids and $\alpha$-dicarbonyls in the mountaintop aerosols over the North China Plain during wheat burning season. Atmos. Chem. Phys. 2013, 13 (16), 8285-8302.

(9) Kundu, S.; Kawamura, K.; Andreae, T. W.; Hoffer, A.; Andreae, M. O. Molecular distributions of dicarboxylic acids, ketocarboxylic acids and $\alpha$-dicarbonyls in biomass burning aerosols: Implications for photochemical production and degradation in smoke layers. Atmos. Chem. Phys. 2010, 10 (5), 2209-2225.

(10) Yang, L.; Nguyen, D. M.; Jia, S.; Reid, J. S.; Yu, L. E. Impacts of biomass burning smoke on the distributions and concentrations of $\mathrm{C}_{2}-\mathrm{C}_{5}$ dicarboxylic acids and dicarboxylates in a tropical urban environment. Atmos. Environ. 2013, 78, 211-218.

(11) Veres, P.; Roberts, J. M.; Burling, I. R.; Warneke, C.; de Gouw, J.; Yokelson, R. J. Measurements of gas-phase inorganic and organic acids from biomass fires by negative-ion proton-transfer chemicalionization mass spectrometry. I. Geophys. Res.: Atmos. 2010, 115, D23302.

(12) Desyaterik, Y.; Sun, Y.; Shen, X.; Lee, T.; Wang, X.; Wang, T.; Collett, J. L. Speciation of "brown" carbon in cloud water impacted by agricultural biomass burning in eastern China. I. Geophvs. Res.: Atmos. 2013, 118 (13), 7389-7399.

(13) Dharaiya, N.; Bahadur, P. Phenol induced growth in Triton X100 micelles: Effect of $\mathrm{pH}$ and phenols' hydrophobicity. Colloids Surf. A 2012, 410, 81-90.

(14) Latif, M. T.; Brimblecombe, P. Surfactants in atmospheric aerosols. Environ. Sci. Technol. 2004, 38 (24), 6501-6506.

(15) Barnum, T. J.; Medeiros, N.; Hinrichs, R. Z. Condensed-phase versus gas-phase ozonolysis of catechol: A combined experimental and ttheoretical study. Atmos. Environ. 2012, 55, 98-106.

(16) Woodill, L. A.; O’Neill, E. M.; Hinrichs, R. Z. Impacts of surface adsorbed catechol on tropospheric aerosol surrogates: Heterogeneous

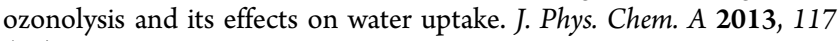
(27), 5620-5631.

(17) Ofner, J.; Krüger, H. U.; Zetzsch, C. Time resolved infrared spectroscopy of formation and processing of secondary organic aerosol. Z. Phvs. Chem. 2010, 224, 1171-1183.

(18) Guzman, M. I.; Athalye, R. R.; Rodriguez, J. M. Concentration effects and ion properties controlling the fractionation of halides during aerosol formation. I. Phvs. Chem. A 2012, 116 (22), 54285435.

(19) Pillar, E. A.; Guzman, M. I.; Rodriguez, J. M. Conversion of iodide to hypoiodous acid and iodine in aqueous microdroplets exposed to ozone. Environ. Sci. Technol. 2013, 47 (19), 10971-10979. 
(20) Yamamoto, Y.; Niki, E.; Shiokawa, H.; Kamiya, Y. Ozonation of organic compounds. 2. Ozonation of phenol in water. I. Org. Chem. 1979, 44 (13), 2137-2142.

(21) Guzman, M. I.; Pillar, E. A. Ozonation of aromatic hydrocarbon probes at the air-water interface. Proceedings of the 248th ACS National Meeting and Exposition; San Francisco, CA, Aug 24-28, 2014; COLL-93.

(22) Graber, E. R.; Rudich, Y. Atmospheric HULIS: How humic-like are they? A comprehensive and critical review. Atmos. Chem. Phys. 2006, 6 (3), 729-753.

(23) CRC Handbook of Chemistry and Physics, 93rd ed.; CRC Press (Taylor and Francis Group): Boca Raton, FL, 2013; p 2664.

(24) Sander, S. P.; Abbatt, J.; Barker, J. R.; Burkholder, J. B.; Friedl, R. R.; Golden, D. M.; Huie, R. E.; Kolb, C. E.; Kurylo, M. J.; Moortgat, G. K.; Orkin, V. L.; Wine, P. H. Chemical Kinetics and Photochemical Data for Use in Atmospheric Studies: Evaluation Number 17; Jet Propulsion Laboratory, California Institute of Technology: Pasadena, CA, 2011; http://jpldataeval.jpl.nasa.gov.

(25) Bailey, P. S. Ozonation in Organic Chemistrvi Academic Press: New York, 1982; Vol. 2.

(26) Gurol, M. D.; Nekouinaini, S. Kinetic behavior of ozone in aqueous solutions of substituted phenols. Ind. Eng. Chem. Fundam. 1984, 23 (1), 54-60.

(27) Standard Reference Database 69: The NIST Chemistry WebBook; Mallard, W. G., Linstrom, P. J., Eds.; National Institute of Standards and Technology (NIST): Gaithersburg, MD, 2000; Vol. 2012, http:// webbook.nist.gov.

(28) Enami, S.; Vecitis, C. D.; Cheng, J.; Hoffmann, M. R.; Colussi, A. J. Global inorganic source of atmospheric bromine. I. Phvs. Chem. A 2007, 111 (36), 8749-8752.

(29) Enami, S.; Vecitis, C. D.; Cheng, J.; Hoffmann, M. R.; Colussi, A. J. Electrospray mass spectrometric detection of products and shortlived intermediates in aqueous aerosol microdroplets exposed to a reactive gas. I. Phvs. Chem. A 2007, 111 (50), 13032-13037.

(30) Steenken, S.; O'Neill, P. Oxidative demethoxylation of methoxylated phenols and hydroxybenzoic acids by the hydroxyl radical. An in situ electron spin resonance, conductometric pulse radiolysis and product analysis study. I. Phys. Chem. 1977, 81 (6), 505-508.

(31) Flyunt, R.; Leitzke, A.; Mark, G.; Mvula, E.; Reisz, E.; Schick, R.; von Sonntag, C. Determination of ${ }^{\bullet} \mathrm{OH}, \mathrm{O}_{2}{ }^{\bullet-}$, and hydroperoxide yields in ozone reactions in aqueous solution. I. Phys. Chem. B 2003, 107 (30), 7242-7253.

(32) Steenken, S.; Neta, P. Properties of phenoxyl radicals. In The Chemistry of Phenols; Rappoport, Z., Ed.; John Wiley and Sons: Hoboken, NJ, 2003; p 1000.

(33) Elliot, A. J.; McCracken, D. R. Effect of temperature on $\mathrm{O}^{\bullet-}$ reactions and equilibria: A pulse radiolysis study. Radiat. Phys. Chem. 1989, 33 (1), 69-74.

(34) Mvula, E.; Schuchmann, M. N.; von Sonntag, C. Reactions of phenol-OH-adduct radicals. Phenoxyl radical formation by water elimination vs. oxidation by dioxygen. J. Chem. Soc., Perkin Trans. 2 2001, No. 3, 264-268.

(35) Adams, G. E.; Michael, B. D. Pulse radiolysis of benzoquinone and hydroquinone. Semiquinone formation by water elimination from trihydroxy-cyclohexadienyl radicals. Trans. Faradav Soc. 1967, 63, $1171-1180$.

(36) Bielski, B. H. J.; Cabelli, D. E.; Arudi, R. L.; Ross, A. B. Reactivity of $\mathrm{HO}_{2} / \mathrm{O}_{2}^{-}$radicals in aqueous solution. I. Phys. Chem. Ref. Data 1985, 14 (4), 1041-1100.

(37) Neta, P.; Huie, R. E.; Ross, A. B. Rate constants for reactions of inorganic radicals in aqueous solution. I. Phys. Chem. Ref. Data 1988, 17 (3), 1027-1284.

(38) Mvula, E.; von Sonntag, C. Ozonolysis of phenols in aqueous solution. Org. Biomol. Chem. 2003, 1 (10), 1749-1756.

(39) Von Sonntag, C.; Von Gunten, U. Chemistry of Ozone in Water and Wastewater Treatment: From Basic Principles to Applications; IWA Publishing: London, U.K., 2012; p 302.
(40) Iwaki, R.; Kamiya, I. Chemiluminescent reaction between polyphenols and ozone in acetic acid. Bull. Chem. Soc. Inn. 1969, 42 (4), 855-863.

(41) Philipp, B.; Schink, B. Evidence of two oxidative reaction steps initiating anaerobic degradation of resorcinol (1,3-dihydroxybenzene) by the denitrifying bacterium Azoarcus anaerobius. I. Bacteriol. 1998, 180 (14), 3644-3649.

(42) Buxton, G. V.; Greenstock, C. L.; Helman, W. P.; Ross, A. B. Critical review of rate constants for reactions of hydrated electrons, hydrogen atoms and hydroxyl radicals $\left({ }^{\circ} \mathrm{OH} /{ }^{\circ} \mathrm{O}^{-}\right)$in aqueous solution. I. Phvs. Chem. Ref. Data 1988, 17 (2), 513-886.

(43) Atkins, P.; De Paula, J. Elements of Physical Chemistry, 6th ed.; W. H. Freeman: New York, 2013; p 630.

(44) Slade, J. H.; Knopf, D. A. Multiphase $\mathrm{OH}$ oxidation kinetics of organic aerosol: The role of particle phase state and relative humidity. Geophvs. Res. Lett. 2014, 41 (14), 5297-5306.

(45) Augugliaro, V.; Rizzuti, L. The $\mathrm{pH}$ dependence of the ozone absorption kinetics in aqueous phenol solutions. Chem. Eng. Sci. 1978, 33 (11), 1441-1447.

(46) Konstantinova, M. L.; Razumovskii, S. D.; Zaikov, G. E. Kinetics and mechanism of the reaction of ozone with phenol in alkaline media. Bull. Acad. Sci. USSR 1991, 40 (2), 266-270.

(47) Ramseier, M. K.; von Gunten, U. Mechanisms of phenol ozonation-Kinetics of formation of primary and secondary reaction products. Ozone: Sci. Eng. 2009, 31 (3), 201-215.

(48) ten Brink, G. J.; Arends, I. W. C. E.; Sheldon, R. A. The BaeyerVilliger reaction: New developments toward greener procedures. Chem. Rev. 2004, 104 (9), 4105-4124.

(49) Criegee, R. Mechanism of ozonolysis. Angew. Chem., Int. Ed. Engl. 1975, 14 (11), 745-752.

(50) Kolsaker, P.; Bernatek, E.; Johanson, R.; Hytta, R. Glyoxylic acid as a reductant in ozonolysis. Acta Chem. Scand. 1973, 27 (5), 15261530.

(51) Tomas, A.; Olariu, R. I.; Barnes, I.; Becker, K. H. Kinetics of the reaction of $\mathrm{O}_{3}$ with selected benzenediols. Int. J. Chem. Kinet. 2003, 35 (6), 223-230.

(52) Seinfeld, J. H.; Pandis, S. N. Atmospheric Chemistry and Physics: From Air Pollution to Climate Change, 2nd ed.; Wiley: New York, 2006; p 1232.

(53) George, I. J.; Abbatt, J. P. D. Heterogeneous oxidation of atmospheric aerosol particles by gas-phase radicals. Nat. Chem. 2010, 2 (9), 713-722.

(54) Rincón, A. G.; Guzmán, M. I.; Hoffmann, M. R.; Colussi, A. J. Optical absorptivity versus molecular composition of model organic aerosol matter. I. Phvs. Chem. A 2009, 113 (39), 10512-10520.

(55) Rincón, A. G.; Guzmán, M. I.; Hoffmann, M. R.; Colussi, A. J. Thermochromism of model organic aerosol matter. L. Phvs. Chem. Lett. 2010, 1 (1), 368-373.

(56) Saleh, R.; Robinson, E. S.; Tkacik, D. S.; Ahern, A. T.; Liu, S.; Aiken, A. C.; Sullivan, R. C.; Presto, A. A.; Dubey, M. K.; Yokelson, R. J.; Donahue, N. M.; Robinson, A. L. Brownness of organics in aerosols from biomass burning linked to their black carbon content. Nat. Geosci. 2014, 7, 647-650.

(57) Saleh, R.; Hennigan, C. J.; McMeeking, G. R.; Chuang, W. K.; Robinson, E. S.; Coe, H.; Donahue, N. M.; Robinson, A. L. Absorptivity of brown carbon in fresh and photo-chemically aged biomass-burning emissions. Atmos. Chem. Phvs. 2013, 13 (15), 76837693. 